\section{Influence of Time and Concentration of 1-MCP Application on the Shelf Life of Pear 'La France' Fruit}

\author{
Yasutaka Kuboํㅡ, Kyoko Hiwasa, Willis Omondi Owino, Ryohei Nakano, \\ and Akitsugu Inaba \\ Faculty of Agriculture, Okayama University, Tsushima-naka, Okayama, \\ Japan 700-8530
}

Additional index words. Pyrus communis, 1-methylcyclopropene, fruit softening, ethylene, respiration

\begin{abstract}
La France' pear (Pyrus communis L.) fruit were exposed to chilling temperature $\left(-1{ }^{\circ} \mathrm{C}\right)$ for a week to induce ethylene biosynthesis before they were transferred to $20{ }^{\circ} \mathrm{C}$ to allow ripening. On 1, 4, or 7 days after the transfer to room temperature, fruit were treated with $20 \mu \mathrm{L} \cdot \mathrm{L}^{-1} 1$-MCP for 12 hours. The 1-MCP treatments suppressed ethylene and carbon dioxide production significantly and slowed fruit softening. The shelf life period of fruit with desirable firmness treated with 1-MCP on day 4 was twice that of untreated fruit, with firmness of 1-MCP treated fruit on day 1 being higher than desirable while that of fruit treated on day 7 was lower than desirable. To determine the optimum 1-MCP concentration for treatment, fruit were exposed to 0.01 to $100 \mu \mathrm{L} \cdot \mathrm{L}^{-1} 1-\mathrm{MCP} 3$ days after the transfer to $20{ }^{\circ} \mathrm{C}$. The fruit treated with $1 \mu \mathrm{L} \cdot \mathrm{L}^{-1} 1-\mathrm{MCP}$ and less ripened similarly to untreated fruit, having a shelf life of a week. 1-MCP treatments of 10 and $100 \mu \mathrm{L} \cdot \mathrm{L}^{-1}$ inhibited ethylene and carbon dioxide production, and delayed fruit softening and occurrence of senescent breakdown. The flesh firmness of these fruit maintained suitable eating quality for more than 3 weeks. Our results indicate that 1 -MCP treatment of $10 \mu \mathrm{L} \cdot \mathrm{L}^{-1}$ at $20^{\circ} \mathrm{C} 3$ to 4 days after initiation of ripening can extend the shelf life of 'La France' pear fruit. Chemical name used: 1-methylcyclopropene (1-MCP).
\end{abstract}

Pear fruit is a typical climacteric fruit that undergoes increase in respiration with a burst of ethylene production during ripening. In commercial practice, pear fruit are harvested at the preclimacteric stage, when the fruit is not ready for eating due to firm flesh and incomplete conversion of starch to sugars. After harvest, fruit are exposed to chilling temperature to induce autocatalytic ethylene and ripening (Knee, 1987). This chilling treatment is absolutely required for normal ripening in some winter pears, such as 'Passe Crassane' (Lelievre et al., 1997), but not always for other cultivars, such as 'La France' and 'Bartlett'. The chilling treatment can be replaced by ethylene treatment in the latter cultivars (Hiwasa et al., 2003). In practice, however, the chilling treatment is applied to 'La France' pears to accelerate and ensure uniform ripening.

The best eating quality of pear fruit, characterized by buttery and juicy flesh with an excellent flavor, is attained during the climacteric stage after storage at ambient room temperature. Ripening processes of pears proceed so quickly that the suitable period for eating is limited. Thus, pear fruit are shipped to market prior to the stage for best eating quality, and

Received for publication 13 Aug. 2002. Accepted for publication 4Feb. 2003. This work was supported in part by Grants-in-Aid for Scientific Research (grant no. 09660029 to Y.K. and 11460013 to A.I.) and JSPS Research Fellowships for Young Scientists (grant no. 6509 to K.H.) from the Ministry of Education, Science, Sports, and Culture of Japan.

${ }^{1}$ To whom reprint requests should be addressed. E-mail: ykubo@cc.okayama-u.ac.jp consumers have to determine the optimum time to eat by themselves. 'La France' pear fruit is popular among Japanese consumers due to its high quality. In addition to its short shelf life, determining the maturity of this cultivar is difficult because fruit color changes little during ripening. A new technique to extend shelf life, where fruit is ripened with desirable firmness for eating, is required to widen the market of pear fruit, especially 'La France'.

A highly potent inhibitor of ethylene action, 1-methylcyclopropene (1-MCP), was developed (Sisler and Serek 1997), and has been registered as a preservative of fresh fruit and vegetables in the United States. It is thought to bind irreversibly to ethylene receptors and protect plants from ethylene. Many reports on efficacy of 1-MCP are available for horticultural crops (Watkins and Miller, 2003). However, most of them have focused on practical applications of 1-MCP to extend postharvest life when it is applied to fruit at the preclimacteric stage, that is, before the induction of autocatalytic ethylene. However, limited information is available on the beneficial effects of 1-MCP when applied to fruit after ripening has been initiated. We previously observed that $1-\mathrm{MCP}$ treatment of ripening pear fruit in which softening had initiated strongly inhibited further softening, with a decrease in the accumulation of mRNAs of the cell wall-associated enzyme polygalacturonase (Hiwasa et al, 2003). This observation indicated that ethylene plays an important role both in initiation and progression of softening, and suggested the possibility of using 1-MCP to extend the shelf life of pears.
The objectives of the present study were to determine the optimum exposure time and concentration of 1-MCPrequired to extend the shelf life of 'La France' pear fruit.

\section{Materials and Methods}

Plant material and treatment. 'La France' pear fruit in commercial maturity, preclimacteric stage, were obtained from a commercial orchard at Yamagata, Japan. Fruit were held at $1{ }^{\circ} \mathrm{C}$ for a week as a chilling treatment and then transferred to $20{ }^{\circ} \mathrm{C}$ to allow ripening. In the first experiment, fruit were exposed to $20 \mu \mathrm{L} \cdot \mathrm{L}^{-1} 1-\mathrm{MCP}$ (EthylBloc ${ }^{\mathrm{TM}}$, Rhome and Hass Co., Springhouse, Pa.) for $12 \mathrm{~h}$ on 1 , 4 , or $7 \mathrm{~d}$ after the transfer from chilling to room temperature. In the second experiment to determine the optimum concentration, fruit were treated with $0,0.01,0.1,1,10$, or 100 $\mu \mathrm{L} \cdot \mathrm{L}^{-1} 1-\mathrm{MCP}$ for $12 \mathrm{~h}$ on $3 \mathrm{~d}$ after the transfer to $20^{\circ} \mathrm{C}$, then allowed to ripen at the same temperature. In both experiments, 50 fruit for each treatment were used. 1-MCP treatments were carried out according to manufacturer's instructions. 1-MCP was generated in a gastight vessel with rubber cap by addition of $0.1 \%$ SDS to EthylBloc powder, and then was injected by a syringe into an airtight, plastic 20-L container enclosing 10 fruit. Rates of ethylene and carbon dioxide production and flesh firmness were determined during ripening at intervals shown in figures.

Determination of ethylene and carbon dioxide production, and flesh firmness. The rates of ethylene production and carbon dioxide production were measured by enclosing individual fruit in an airtight chamber for $1 \mathrm{~h}$ at 20 ${ }^{\circ} \mathrm{C}$, withdrawing $1 \mathrm{~mL}$ of headspace gas from the chamber for each determination, and injecting it into a gas chromatograph (model GC4CMPE, Shimadzu, Kyoto, Japan). Ethylene and carbon dioxide were analyzed by a flame ionization detector with an activated alumina column and a thermal conductivity detector with Porapak Q column, respectively. In both gas analyses, measurements were replicated five times in each time point using the same five fruit per treatment. Firmness was measured at four equatorial regions of the peeled fruit using a penetrometer (model SMT-T-50, Toyo Baldwin, Tokyo) fitted with a plunger (8- mm diameter; penetration speed: $30 \mathrm{~mm} \cdot \mathrm{min}^{-1}$ ) and the firmness of one fruit was represented by mean value of four sides. The firmness measurement was carried out using five fruit at each time point. As the fruit was damaged by the measurement, five additional fruit were used at each time point.

\section{Results and Discussion}

Time of 1-MCP treatment after ripening induction. Untreated fruit produced ethylene upon transfer to $20{ }^{\circ} \mathrm{C}$ after a week at $-1{ }^{\circ} \mathrm{C}$ (Fig. 1A). The climacteric peaks in respiration (Fig. 1B) and ethylene production (Fig. 1A) were observed on 7 and $14 \mathrm{~d}$ after the transfer, respectively. The fruit on $1 \mathrm{~d}$ after the transfer was as firm as at harvest, and then softened rapidly (Fig. 1C). Flesh firmness reached the 


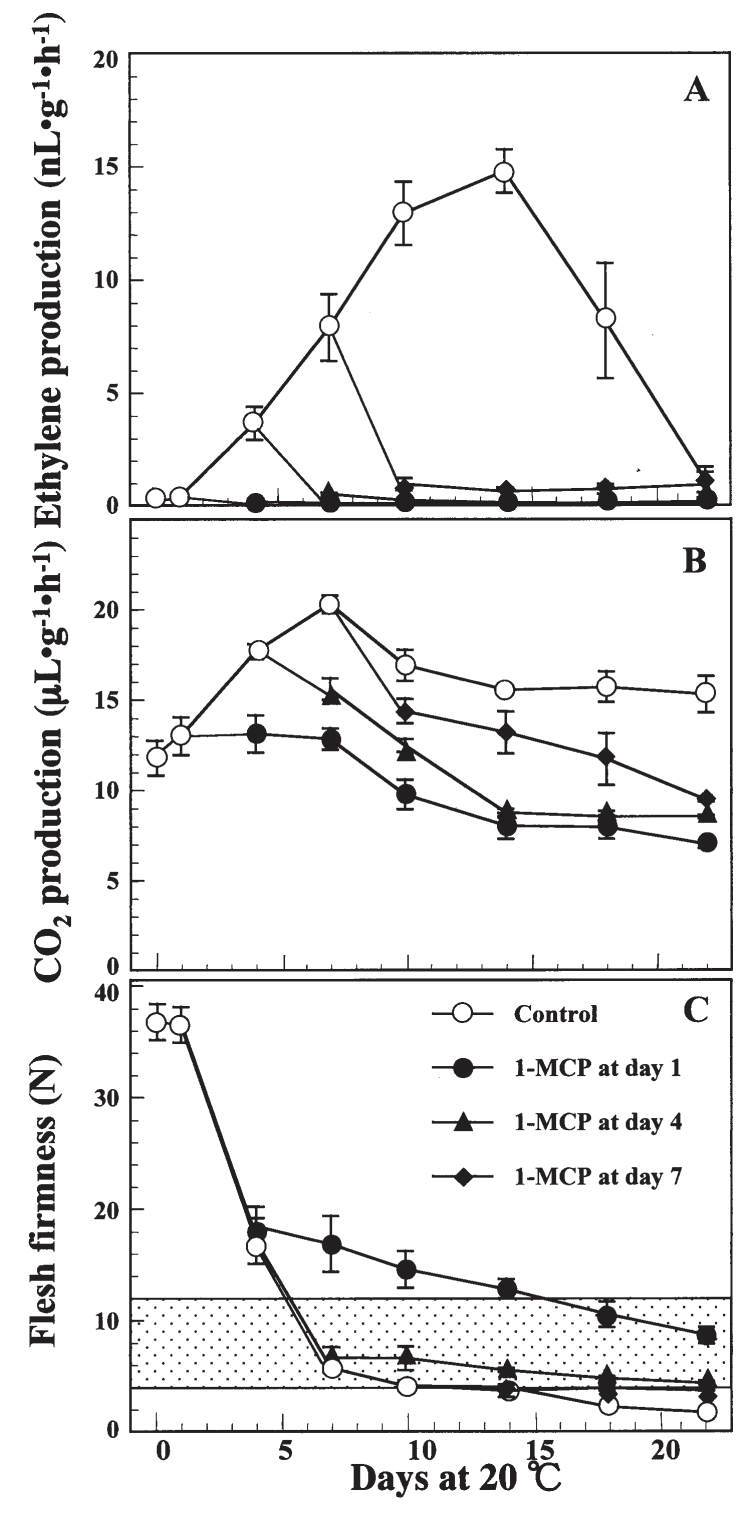

Fig. 1. Rates of $(\mathbf{A})$ ethylene and $(\mathbf{B})$ carbon dioxide production and $(\mathbf{C})$ flesh firmness in 'La France' pear fruit treated with $20 \mu \mathrm{L} \cdot \mathrm{L}^{-1} 1-\mathrm{MCP}$ for $12 \mathrm{~h}$ at various times after transfer to room temperature from chilling treatment at $1{ }^{\circ} \mathrm{C}$ for 1 week. Boxed area for flesh firmness shows the range that is suitable for eating and the best buttery texture is obtained around $6 \mathrm{~N}$ (firmness of $40 \mathrm{~N}$ and above, hard and crispy texture at harvest; that of more than $12 \mathrm{~N}$, firm; that of less than $4 \mathrm{~N}$, too soft and jelly-like). Vertical bars show standard errors $(n=5)$.

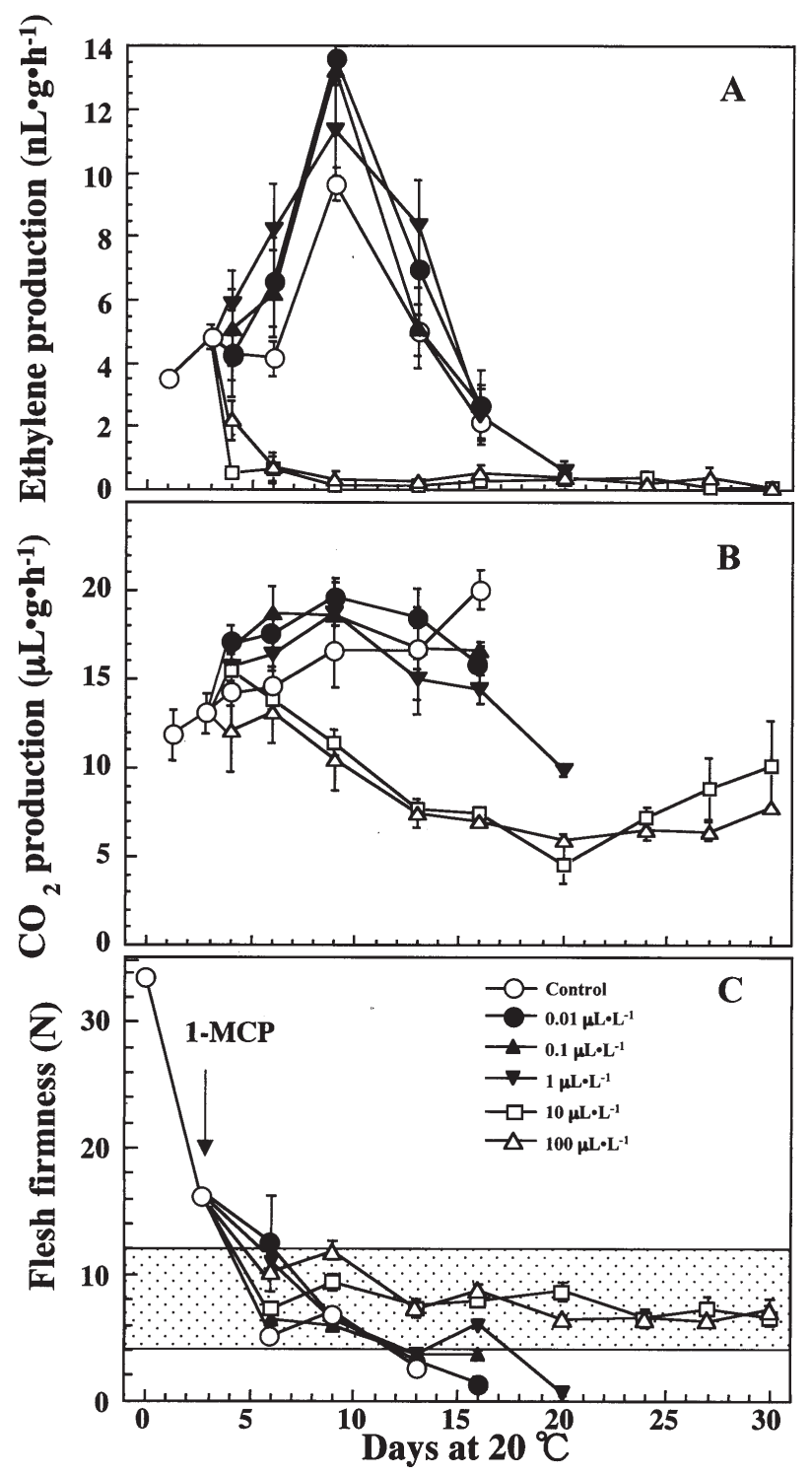

Fig. 2. Rates of (A) ethylene and (B) carbon dioxide production and (C) flesh firmness in 'La France' pear fruit treated with different concentration of 1 -MCP for $12 \mathrm{~h}$ at various concentration on $3 \mathrm{~d}$ after transfer to room temperature from chilling treatment at $1{ }^{\circ} \mathrm{C}$ for 1 week. Boxed area in flesh firmness shows the range suitable for eating and the best buttery texture is obtained around $6 \mathrm{~N}$ (firmness of $40 \mathrm{~N}$ and above, hard and crispy texture at harvest; that of more than $12 \mathrm{~N}$, firm; that of less than $4 \mathrm{~N}$, too soft and jelly-like). Vertical bars show standard errors $(n=5)$. upper limit of acceptable eating quality range on $\mathrm{d} 5$, then decreased to the lower limit on $\mathrm{d} 12$. Therefore, the period suitable for eating non-treated fruit was about a week at room temperature.

Treating with $20 \mu \mathrm{L} \cdot \mathrm{L}^{-1} 1-\mathrm{MCP}$ for $12 \mathrm{~h}$ on 1,4 , or $7 \mathrm{~d}$ after the transfer to room temperature decreased ethylene production to trace levels immediately, and the ethylene production was suppressed until the end of the experiment. It confirmed that ripening ethylene in pears is totally regulated by a positive feedback manner, as shown for tomatoes (Nakatsuka et al., 1998). It took $3 \mathrm{~d}$ before effects of 1-MCP on fruit softening were detectable. The flesh firmness of the 1-MCP treated fruit decreased similar to that of untreated fruit for the first $3 \mathrm{~d}$ after the treatment. Then, further softening of the treated fruit was markedly arrested. The discrepancy in the response time to $1-\mathrm{MCP}$ between ethylene production and softening could be associated with differences in turnover of enzymes responsible for ethylene biosynthesis and for cell wall modification. The flesh firmness of fruit treated with $1-\mathrm{MCP}$ on $\mathrm{d} 1$ gradually declined and reached the maximum limit of acceptable range after $\mathrm{d} 14$. The 1-MCP treatment on $\mathrm{d} 4$ maintained flesh firmness within an acceptable range from $\mathrm{d} 7$ to $\mathrm{d} 22$, thus extending shelf life to 2 weeks, double that of untreated fruit. Similar effects were observed in the treatment on $\mathrm{d} 7$ although firmness after treatment at this time might be too soft for transportation of fruit.

1-MCP treatment at the preclimacteric stage has been shown to extend postharvest life in various fruit, vegetables, and flowers (Watkins and Miller, 2003). When 1-MCP is applied to fruit at climacteric stage, it significantly delays some ripening-associated events, such as color development in tomatoes (Nakatsuka et al., 1998) and bananas (Golding et al., 1998), volatile production in bananas (Golding et al., 1998), and fruit softening in apples (Fan et al., 1999; Rupasinghe et al., 2000; Watkins et al., 2000). In pear fruit also, 1-MCP treatment during chilling exposure suppresses the subsequent ethylene production (Lelievre et al., 1997). Consumers prefer firm apple fruit. Early or continuous treatment of 1-MCP would be better for apples under commercial practice, whereas quality pear fruit are characterized by a soft and melting texture. 1-MCP treatment after initiation of the softening process could provide a way to obtain high-quality pear fruit in the market. The present results suggest that 1-MCP treatment $4 \mathrm{~d}$ after transfer to room 
temperature or slightly earlier can extend the shelf life of fruit, with suitable firmness, by twice that of untreated fruit. 1-MCP treatment 1 and $7 \mathrm{~d}$ after the transfer might be preferable for long distance markets and very short transportation, respectively.

Concentration of 1-MCP treatment. Since 1-MCP has relatively greater affinity than ethylene for ethylene-binding site (Jiang et al., 1999, Zhang and Warner, AgroFresh Inc., personal communication), it is often effective at very low concentration, as low as $0.1 \mu \mathrm{L} \cdot \mathrm{L}^{-1}$. However, there is a considerable difference in the concentration of 1-MCP necessary for a maximum response in different plants (Sisler and Serek, 1997). Sisler and Serek (1997) described that 1-MCP completely protects carnation and banana from ethylene by a 24h exposure at $0.5 \mathrm{~nL} \cdot \mathrm{L}^{-1}$. Treatment with 40 $\mathrm{nL} \cdot \mathrm{L}^{-1}$ results in complete inhibition of ethylene effects in pea seedlings. Jiang et al. (1999) indicated a concentration of $50 \mathrm{~nL} \cdot \mathrm{L}^{-1}$ as the saturating concentration in green banana in order to protect from ethylene. Treatment for $24 \mathrm{~h}$ with $30-70 \mathrm{~nL} \cdot \mathrm{L}^{-1} 1-\mathrm{MCP}$ to avocado fruit at preclimacteric stage significantly delayed onset of ripening, with a small difference among treated concentrations (Feng et al., 2000). In Japanese persimmon fruit, we observed that inhibitory effect of 1-MCP on postharvest softening is saturated at $100 \mathrm{~nL} \cdot \mathrm{L}^{-1}$ when it is treated for $12 \mathrm{~h}$ immediately after harvest (Harima et al., 2002). Rupasinghe et al. (2000) demonstrated that the concentration of 1-MCP necessary for maximum response in ethylene production and fruit softening in apples is 1 $\mu \mathrm{L} \cdot \mathrm{L}^{-1}$ when applied immediately after harvest. All of the examples described above are the cases in which 1-MCP is treated before ripening-or senescence-associated massive ethylene (system 2 ethylene) has produced.

The changes in flesh firmness, ethylene production, and carbon dioxide production of 'LaFrance' fruit treated with 1-MCP at $1 \mu \mathrm{L} \cdot \mathrm{L}^{-1}$ or less were similar to those of untreated fruit (Fig. 2A-C). On the other hand, the treatments at 10 and $100 \mu \mathrm{L} \cdot \mathrm{L}^{-1}$ immediately reduced ethylene production to trace levels and prevented the subsequent increase in respiration and fruit softening. The flesh firmness in fruit treated with $1-\mathrm{MCP}$ at 10 and $100 \mu \mathrm{L} \cdot \mathrm{L}^{-1}$ remained at suitable range for more than 3 weeks (Fig. $2 \mathrm{C})$. In treatments with $1-\mathrm{MCP}$ at $1 \mu \mathrm{L} \cdot \mathrm{L}^{-1}$ or less, senescent breakdown was observed in some fruit on d 16 and all fruit were damaged before $\mathrm{d} 20$. However, no senescent breakdown occurred in fruit treated with 10 and $100 \mu \mathrm{L} \cdot \mathrm{L}^{-1}$ 1-MCP even on d 20 (Fig. 3). These observations suggest that 1-MCP concentration of 10 $\mu \mathrm{L} \cdot \mathrm{L}^{-1}$ is required for inhibitory effect on the subsequent softening in ripening pear fruit. This $1-\mathrm{MCP}$ concentration is much higher than that mentioned above in crops producing only basal ethylene (system 1 ethylene). When $1-\mathrm{MCP}$ is treated at climacteric stage, it would compete



Fig. 3. Cross-section on d 20 of 'La France' pear fruit treated with 1-MCP at various concentrations 3 d after transfer to room temperature from chilling treatment at $1{ }^{\circ} \mathrm{C}$ for 1 week.

with endogenous ethylene for binding site of receptors. Therefore, higher concentration of 1-MCP would be necessary to exhibit its inhibitory effect on ethylene action. Another possible explanation for requirement of high 1 -MCP concentration in pear fruit is low affinity of 1-MCP to ethylene receptor of pear fruit. 1-MCP treatment at $4 \mu \mathrm{L} \cdot \mathrm{L}^{-1}$ during storage has been shown to block chilling-induced ACC synthase and ACC oxidase transcripts and ethylene production of preclimacteric 'Passe-Crassane' pears after the transfer to room temperature (Lelievre et al., 1997). Investigation of the dose response of 1-MCP to preclimacteric pears would be helpful to clarify the two possibilities.

In conclusion, our results indicate that 1MCP treatment has a great potential to maintain a desirable firmness suitable for eating in pear fruit and extends its shelf life. As the current maximum registered dosage of 1-MCP for food is $1 \mu \mathrm{L} \cdot \mathrm{L}^{-1}$ in the United States, further investigation is required for commercial use of 1-MCP to extend shelf life of pears.

\section{Literature Cited}

Fan, X., S.M. Blankenship, and J.P. Mattheis. 1999. 1-Methylcyclopropene inhibits apple ripening. J. Amer. Soc. Hort. Sci. 124:690-695.

Feng, X., A. Apelbaum, E.C. Sisler, and R. Goren. 2000. Control of ethylene response in avocado fruit with 1-methylcyclopropene. Postharvest Biol. Technol. 20:143-150.

Golding, J.B., D. Shearer, S.G. Wyllie, and W.B. McGlasson. 1998. Application of 1-MCP and propylene to identify ethylene-dependent ripening processes in mature banana fruit. Postharvest Biol. Technol. 14:87-98.

Harima, S., R. Nakano, K. Yamamoto, Y. Kitano, Y. Yamamoto, A. Inaba, and Y. Kubo. 2003. Extended shelf-life of astringent type Japanese persimmon (Diospyros kaki Thunb.) fruit by 1MCP. Postharvest Biol. Technol. 29:319-324.
Hiwasa, K., Y. Kinugasa, S. Amano, A. Hashimoto, R. Nakano, A. Inaba, and Y. Kubo. 2003. Ethylene is required for both the initiation and progression of softening in pear (Pyrus communis L.) fruit. J. Expt. Bot. 383:771-779.

Knee, M. 1987. Development of ethylene biosynthesis in pear fruit at $-1^{\circ} \mathrm{C}$. J. Expt. Bot. 38: 1724-1733.

Jiang, Y., D.C. Joyce, and A.J. Macnish. 1999. Extension of the shelf life of banana fruit by 1-methylcyclopropene in combination with polyethylene bags. Postharvest Biol. Technol. 16:187-193.

Lelievre, J.M., L. Tichit, P. Dao, L. Fillion, Y.W. Nam, J.C. Pech, and A. Latche. 1997. Effects of chilling on the expression of ethylene biosynthetic genes in Passe-Crassane pear (Pyrus communis L.) fruit. Plant Mol. Biol. 33:847-855.

Nakatsuka, A., S. Murachi, H. Okunishi, S. Shiomi, R. Nakano, Y. Kubo, and A. Inaba. 1998. Diffential expression and internal feedback regulation of 1-aminocyclopropene-1-carboxylate synthase, 1-aminocyclopropene-1-carboxylate oxidase, and ethylene receptor genes in tomato fruit during development and ripening. Plant Physiol. 118:1295-1305.

Rupasinghe, H.P.V., D.P. Murr, G. Paliyath, and Skog. 2000. Inhibitory effect of 1-MCP on ripening and superficial scald development in 'McIntosh' and 'Delicious' apples. J. Hort. Sci. Biotechnol. 75:271-276.

Sisler, E.C. and M. Serek. 1997. Inhibitors of ethylene responses in plants at receptor level: Recent developments. Physiol. Plant. 100:577-582.

Watkins, C.B., J.F. Nock, and B.D. Whitaker. 2000. Responses of early, mid and late season apple cultivars to postharvest application of 1-methylcyclopropene (1-MCP) under air and controlled atmosphere storage conditions. Postharvest Biol. Technol. 19:17-32.

Watkins, C.B and W.B. Miller. 2003. A summary of physiological processes or disorders in fruits, vegetables and ornamental products that are delayed or decreased, increased, or unaffected by application of 1-methylcyclopropene (1-MCP). <http://www.hort.cornell.edu/department/ faculty/watkins/ethylene> 